\title{
Association between demarcated enamel hypomineralization on second primary molars and dental caries in childhood
}

\author{
Cristiane M. Costa-Silva', Glaucia M.B. Ambrosano², Fábio L. Mialhe² \\ 1. Centro Universitário das Faculdades Associadas de Ensino - UNIFAE, São João da Boa Vista, São Paulo, Brasil \\ 2. Universidade Estadual de Campinas. Faculdade de Odontologia de Piracicaba. Piracicaba, São Paulo, Brasil.
}

\begin{abstract}
Hypomineralized Second Primary Molars (HSPM) is the name used to describe the presence of demarcated enamel hypomineralization in second primary molars. HSPM has been compared with Molar Incisor Hypomineralization (MIH) as regards its clinical appearance and consequences. The aim of this study was to investigate associations between HSPM and dental caries in childhood. It was a cross-sectional populationbased study that included 216 children aged 4-6 years from public schools in Botelhos, Brazil. Children with all second primary molars erupted were eligible for participation. Clinical examination was performed by one calibrated examiner. HSPM was recorded according to modified European Academy of Paediatric Dentistry criteria. The main outcome was dental
\end{abstract}

caries experience as indicated by the dmft index (\%dmft $>0)$ according to WHO criteria. Chi-square test and Logistic Regression Model were used to adjust the results for effects of covariates Among the 216 children examined, 22.2\% presented HSPM. After adjustment for logistic regression, children with HSPM were found to have a 2.28 times greater chance of presenting dental caries. Our results reinforce the importance of HSPM in caries development in children, which should be considered by public health dentists in the process of planning actions aimed at this population.

Received: August 2020; Accepted: October 2020.

Keywords: children - tooth demineralization - dental caries DMF Index - socioeconomic factors

\section{Associações entre hipomineralização demarcada de esmante nos segundos molares decíduos e cárie dentária na infância}

\begin{abstract}
RESUMO
A hipomineralizacao de segundo molar decíduo (HSMD) é denominação utilizada para descrever a presença de hipomineralização demarcada do esmalte nos segundos molares decídus. A HSMD foi comparada com a hipomineralização de molares e incisivos (HMI) no que diz respeito à aparência e às consequências clínicas. O objetivo deste estudo foi investigar associações entre HSMD e cárie na infância. Foi realiza um estudo transversal de base populacional, composto por 216 crianças de 4 a 6 anos de idade de escolas públicas de Botelhos, Brasil. As crianças com todos os segundos molares decíduos foram elegíveis para participação. O exame clínico foi realizado por um examinador calibrado. A HSMD foi registrada de acordo com os critérios modificados da European Academy of Paediatric Dentistry. O desfecho principal foi a experiência de cárie
\end{abstract}

\section{INTRODUCTION}

Hypomineralized second primary molars (HSPM), a qualitative developmental defect of enamel (DDE), with a demarcated change in translucency or opacity, are often found in children ${ }^{1,2}$. HSPM has been dentária nos dentes decíduos conforme o índice ceo (\% ceo> $0)$, segundo os critérios da OMS. Os testes de Qui-quadrado e o modelo de regressão logística foram utilizados para ajustar os resultados dos efeitos das covariáveis. Verificou-se que entre as 216 crianças examinadas, 22,2\% apresentaram HSMD. Após o ajuste da regressão logística, as crianças com HSMD tiveram 2,28 vezes mais chances de apresentar cárie dentária. Nossos resultados reforçam a importância do HSMD no desenvolvimento da cárie em crianças, fato que deve ser considerado pelos dentistas de saúde pública no processo de planejamento de ações voltadas a essa população.

Palavras-chave: crianças - hipomineralização dentária - cárie dentária - fatores socioeconômicos

compared with Molar Incisor Hypomineralization $(\mathrm{MIH})$ as regards its clinical appearance and consequences $^{3}$, and the diagnostic criteria proposed by the European Academy of Paediatric Dentistry 
(EAPD) in $2003^{4}$ have been used in clinical studies to describe the prevalence of HSPM ${ }^{1}$.

The exact mechanism and etiological factors underlying MIH and HSPM are not fully understood $^{5,6}$, however, researchers agree that fluoride intake is not implicated in the aetiology of demarcated enamel opacity ${ }^{5}$. As the formation of second primary molars coincides with that of permanent first molar formation, a common cause for the both MIH and HSPM processes may be considered ${ }^{7}$, which would explain the higher prevalence of MIH among children with HSPM in deciduous dentition ${ }^{2,3,7}$.

DDE is often associated with higher caries levels among affected children, including dental caries in childhood ${ }^{8}$. In Brazil, for example, a prospective study suggested that the presence of DDE was the main risk factor associated with the development of caries in 36-month-old children of low socioeconomic status, surpassing other classic risk factors such as night-time breast-feeding and tooth-brushing habits9. Studies have demonstrated a positive association between demarcated enamel opacity and dental caries in children worldwide ${ }^{8,10-12}$. However, in spite of such evidence, several confounding factors can interfere in the results of those associations, e.g., access to fluoridated water, oral hygiene status of children, and socioeconomic factors such as education and family income.

Particularly in developing countries such as Brazil, a country marked by strong geographical contrasts regarding children's access to dental care ${ }^{13}$, understanding the relationship between enamel defects and caries could contribute to guiding more effective public health measures. The aim of this study was to investigate associations between HSPM and dental caries in Brazilian children aged 4 to 6 years from Botelhos, Minas Gerais, and to investigate the influence of clinical and demographic factors on the occurrence of caries in the primary dentition. The hypothesis was that even in populations with low socio-economic status, HSPM acts as a risk factor for caries.

\section{MATERIAL AND METHODS}

Approval for this study was obtained from the Ethics Committee of the Piracicaba Dental School, São Paulo, Brazil (Protocol 037/2010) and the procedures followed were in accordance with the ethical standards of the Helsinki Declaration of
1975, as revised in 2000. Participants' parents provided informed consent before the study began.

This was a cross-sectional population-based study. Children aged 4 to 6 years from public schools in Botelhos, Minas Gerais (which has a population of just over 15 thousand) were invited to this study. Children were excluded if they were absent on the day of the examination, if their parents declined to provide consent or if they did not present all 4 deciduous second molars at the time of examination ${ }^{14}$. Data were collected by means of a structured questionnaire that had been previously verified for clarity of the questions. The questionnaire was used to collect sociodemographic information related to the children and was completed by the parents. The sociodemographic factors were children's age (dichotomized by median) and gender (male or female), place of residence (rural or urban) and access to fluoridated water (yes/no).

The examination was carried out at the schools by the first author (CMCS) in accordance with the World Health Organisation (WHO) criteria $^{15}$, under natural light, with the aid of a mouth mirror, wooden spatula and gauze, strictly following biosafety standards.

The presence of visible plaque on the buccal surface of upper incisors, central and lateral incisors $(52,51$, 61,62 ) was recorded (yes/no) before the children brushed their teeth. If the child had plaque on two or more incisors, it was considered as visible plaque present (yes), otherwise, it was considered absent (no).

Before the examination for dental caries and HSPM, the participating children were given toothbrushes and toothpaste to brush their teeth under the researcher's supervision. Dental caries was assessed using the decayed, missing and filled tooth index (dmft) in accordance with the $\mathrm{WHO}^{15}$. Children were classified as with HSPM if they had demarcated opacity, atypical restoration or structural loss in one or more deciduous second molars ${ }^{16}$.

The median $\mathrm{dmft}$ was calculated and information was also collected on the number of primary teeth with treatment needs, in accordance with the international methodological criteria defined by the $\mathrm{WHO}^{15}$ (one or more teeth need fillings, extraction, pulp care, crown), and after this, the frequency of children in need of dental treatment (yes/no) was assessed. All participants were informed about the screening outcome and referred to public dental care for treatment when oral diseases were identified. 
Prior to calibration, the authors adjusted the criteria for the diagnosis of HSPM, using clinical photographs of children with enamel defects. For calibration, 20 children belonging to the same age group were randomly selected and examined. In order to determine intra-examiner agreement, the children were re-examined after an interval of 24 hours, without access to the previous records. Kappa statistics were used to measure concordance. The kappa values for intra-examiner reliability regarding the presence of dental caries, treatment needs and HSPM were 0.92, 0.92 and 0.94, respectively.

All statistical analyses were performed with the software program SAS 9.2 for Windows (SAS Institute Inc. Cary, NC, USA). The presence of HSPM defects (yes/no) was analyzed as a dependent variable. The Odds Ratio (OR) and confidence intervals $(\mathrm{CI})$ were calculated and p-values were obtained using the Chi-square test.

The clinical and demographic characteristics of children with and without HSPM were compared. A Logistic Regression Model was used to adjust the OR for the effects of covariates. Only variables with $\mathrm{p}<0.2$ in the bivariate analyses were selected for the model. The variables that remained in the Logistic Regression Model at $\mathrm{p}<0.05$ were considered statistically significant and the result of logistic regression was accepted only if approved by the Hosmer-Lemeshow goodness-of-fit statistics.

\section{RESULTS}

A total 216 children $(52.7 \%$ girls; median age $=5)$ who were present on the day of examination and whose guardians had filled out and signed the free and informed consent form, were enrolled in this study. Overall, 35 (16.3\%) children lived in rural areas and did not have access to fluoridated water. There were no significant differences in the prevalence of HSPM by sex or other sociodemographic characteristics of children (Table 1).

Among the 216 children examined, 22.2\% ( $\mathrm{n}=$ 48) presented HSPM. At tooth level, 64 of the 864 primary second molars scored were diagnosed with HSPM (7.4\%). No differences were found in the presence of HSPM either between mandible and maxilla or between left and right sides. Demarcated enamel opacities $(89 \%)$ were the most frequently scored characteristics of HSPM, followed by atypical restorations $(6.1 \%)$ and post-eruptive enamel loss $(4.9 \%)$.
Caries prevalence was expressed as the percentage of individuals in each group with $\mathrm{dmft}>0$. Among 216 children, $55.5 \%(\mathrm{n}=120)$ presented $\mathrm{dmft}>0$ and, of these, $81.16 \%(\mathrm{n}=101)$ presented treatment needs at the time of examination. The maximum $\mathrm{dmft}$ score was 19. Mean dmft was $2.45(\mathrm{sd}=3.30)$, and the overall median dmft was 1 . Visible plaque was present in $43.5 \%$ of children. The frequency of HSPM, dental caries, treatment needs and visible plaque are presented in Table 2.

The bivariate and multiple analyses at child level using the presence of HSPM as the exploratory factor are shown in Table 3.

Bivariate logistic regression showed that children with HSPM presented more treatment need, visible plaque on the buccal surface of upper incisors, and more experience of $\mathrm{dmft}$ than children without HSPM. However, after adjusting by logistic, the model showed that children with HSPM had a 2.28 times greater chance of having dental caries in deciduous teeth.

\section{DISCUSSION}

Reports of clinical studies on the prevalence of demarcated enamel hypomineralization in second primary molars and dental caries in primary dentition demonstrate that this enamel defect is associated with a greater experience of caries in deciduous dentition, when compared to children without HSPM ${ }^{1,2,7,12}$. This study, carried out with Brazilian children, confirms previous results and highlights the importance of public health dentists paying attention to this clinical aspect when planning actions aimed at children.

From a biochemical point of view, teeth with enamel hypomineralization are at higher risk for dental caries, probably due to their higher porosity and lower mechanical resistance factors ${ }^{16,17}$, which predispose the enamel to post-eruptive tooth breakdown, mainly in teeth with brown and yellow opacities ${ }^{18}$, and create a suitable local environment for adhesion and colonization of cariogenic bacteria.

In this population-based study, $22.2 \%$ of the children examined, who were all 4-6 years old, were found to have HSPM. The prevalence of HSPM found in this group was higher than the prevalence reported in literature ${ }^{1,2,7,12}$. Clinical studies on the prevalence of demarcated hypomineralization in deciduous teeth using the DDE index ${ }^{15}$ report widely varying prevalence rates. It was difficult to compare the 


\begin{tabular}{|c|c|c|c|c|c|c|}
\hline Sociodemographic factors & $\begin{array}{c}\text { Yes } \\
\text { N (\%) }\end{array}$ & $\begin{array}{c}\text { No } \\
\text { N (\%) }\end{array}$ & $\begin{array}{l}\text { Total } \\
\text { N (\%) }\end{array}$ & p value* & OR & Cl $95 \%$ \\
\hline \multicolumn{7}{|l|}{$\operatorname{Sex}(n=216)$} \\
\hline Male & $23(22.55)$ & $79(77.45)$ & $102(100)$ & 0.9130 & 1.04 & \\
\hline Female & $25(21.93)$ & $89(78.07)$ & $114(100)$ & & Ref & $0.54-1.97$ \\
\hline \multicolumn{7}{|l|}{ Age in years $(n=216)$} \\
\hline$>5$ & $17(18.89)$ & $73(81.11)$ & $90(100)$ & 0.3193 & 0.71 & \\
\hline$\leq 5$ & $31(24.61)$ & 95 (76.19) & $126(100)$ & & Ref & $0.37-1.39$ \\
\hline Place of residence $(n=215)$ & & & & 0.4210 & & \\
\hline Rural & $6(17.14)$ & $29(82.86)$ & $35(100)$ & & 0.70 & \\
\hline Urban & $42(23.33)$ & $138(76.67)$ & $180(100)$ & & Ref & $0.36-1.75$ \\
\hline \multicolumn{7}{|l|}{ Access to fluoridated water $(n=209)$} \\
\hline Yes & $41(23.42)$ & $134(76.58)$ & $175(100)$ & 0.2613 & Ref & \\
\hline No & $5(14.70)$ & $29(85.30)$ & $34(100)$ & & 0.56 & $0.20-1.55$ \\
\hline
\end{tabular}

Table 2. HSPM, treatment needs, visible plaque on the buccal surface of upper incisors and experience of caries ( $\mathrm{dmft}$ ) according to age of children in the sample.

\begin{tabular}{|c|c|c|c|c|c|c|c|c|c|c|}
\hline \multirow[b]{2}{*}{$\begin{array}{l}\text { Age in } \\
\text { years }\end{array}$} & \multicolumn{2}{|c|}{ HSPM } & \multicolumn{2}{|c|}{ Treatment needs } & \multicolumn{2}{|c|}{ Visible plaque } & \multicolumn{3}{|c|}{ Caries experience } & \multirow{2}{*}{$\begin{array}{l}\text { Total } \\
\mathrm{N}(\%)\end{array}$} \\
\hline & $\begin{array}{c}\text { Yes } \\
\text { N (\%) }\end{array}$ & $\begin{array}{c}\text { No } \\
\mathrm{N}(\%)\end{array}$ & $\begin{array}{c}\text { Yes } \\
N(\%)\end{array}$ & $\begin{array}{c}\text { No } \\
N(\%)\end{array}$ & \begin{tabular}{c}
\multicolumn{2}{c}{ Yes } \\
$N \quad(\%)$
\end{tabular} & $\begin{array}{l}\text { No } \\
N\end{array}$ & $\begin{array}{l}\mathrm{dmft}=0 \\
\mathrm{~N} \quad(\%)\end{array}$ & $\begin{array}{l}\mathrm{dmft}>0 \\
\mathrm{~N} \quad(\%)\end{array}$ & Mean (SD) & \\
\hline 4 & $15(28.84)$ & $37(71.16)$ & $21(40.38)$ & $31(59.62)$ & $19(36.53)$ & $33(63.47)$ & $29(55.77)$ & $23(44.23)$ & $1.77( \pm 2.82)$ & $52(100)$ \\
\hline 5 & $16(21.62)$ & $58(78.38)$ & $35(47.30)$ & $39(52.70)$ & $26(35.13)$ & $48(64.87)$ & $32(43.25)$ & $42(56.75)$ & $2.55( \pm 3.58)$ & $74(100)$ \\
\hline 6 & $17(18.89)$ & $73(81.11)$ & $45(50.00)$ & $45(50.00)$ & $49(55.45)$ & $41(45.55)$ & $35(38.89)$ & $55(61.11)$ & $2.77( \pm 3.29)$ & $90(100)$ \\
\hline Total & $48(22.22)$ & 168 (77.78) & $101(46.75)$ & 115 (53.25) & 94 (43.52) & $122(56.48)$ & 96 (44.45) & 120 (55.56) & $2.45( \pm 3.30)$ & 216 (100) \\
\hline
\end{tabular}

results of the various studies because of examination variability, methods of recording and different age groups. However, the prevalence of other developmental defects of enamel varies considerably around the world and the same variation has been observed for permanent teeth. In the case of MIH, there was a prevalence of $2.5 \%$ among Chinese children ${ }^{19}$ while in Brazil, for the same city as the one considered in this study, a prevalence of $19.8 \%$ was reported among children aged 6 to 12 years ${ }^{20}$.

HSPM has been compared with $\mathrm{MIH}$ regarding several aspects, such as asymmetric distribution in the dentition, and clinical consequences such as post-eruptive enamel breakdown and presence of atypical restorations ${ }^{7}$. The same possible causes of MIH are mentioned for HSPM $^{1}$, and researchers agree that fluoride intake is not implicated in the aetiology of $\mathrm{MIH}^{5}$. In this study, there was no difference in prevalence of enamel defects in children living in fluoridated and non-fluoridated areas. Hence, the prevalence of HSPM, as in the case of MIH, seems to be unaffected by environmental fluoride levels. However, it must be considered that access to fluoridated water can contribute to a lower prevalence of caries among children with qualitative enamel defects.

In Brazil, residents in rural areas are at greater risk for the development and aggravation of dental diseases due to their more limited access to public health services and interventions such as community water fluoridation ${ }^{13,21}$. In addition, some of these factors are linked to unfavourable socioeconomic contexts such malnutrition and other socially dependent factors that may influence the incidence of enamel defects on a population basis. Although previous studies have shown higher prevalence of MIH in rural areas ${ }^{19}$, this study did not corroborate that fact, probably due its small sample size. Despite being a population-based study, we used a small sample of children, all from public schools, which may interfere in the results referring to sociodemographic data and its relationship with HSPM, since other studies 
Table 3. Association between children's clinical factors and HSPM

\begin{tabular}{|c|c|c|c|c|c|c|c|c|}
\hline \multirow[b]{2}{*}{ Clinical variables } & \multicolumn{2}{|c|}{ HSPM } & \multirow[b]{2}{*}{$\begin{array}{l}\text { Total } \\
\text { N (\%) }\end{array}$} & \multirow[b]{2}{*}{ P value* } & \multirow[b]{2}{*}{ OR } & \multirow[b]{2}{*}{ Cl 95\% } & \multirow[b]{2}{*}{$\begin{array}{c}\text { Adjusted } \\
\text { OR }\end{array}$} & \multirow[b]{2}{*}{$\mathrm{Cl} 95 \%$} \\
\hline & $\begin{array}{c}\text { Yes } \\
\text { N (\%) }\end{array}$ & $\begin{array}{c}\text { No } \\
\text { N (\%) }\end{array}$ & & & & & & \\
\hline \multicolumn{9}{|c|}{ Decayed deciduous teeth } \\
\hline$d=0$ & $13(13.54)$ & $83(86.46)$ & $96(100)$ & & Ref & & & \\
\hline$d>0$ & $35(29.17)$ & $85(70.83)$ & $120(100)$ & 0.0061 & 2.63 & $1.30-5.32$ & 2.28 & $1.04-4.98$ \\
\hline \multicolumn{9}{|c|}{ Dental caries experience } \\
\hline Children with $\mathrm{dmft} \leq 1$ & $17(15.04)$ & $96(84.96)$ & $113(100)$ & & Ref & & & \\
\hline Children with dmft > 1 & $31(30.09)$ & $72(69.91)$ & $103(100)$ & 0.0079 & 2.43 & $1.25-4.73$ & & \\
\hline \multicolumn{9}{|l|}{ Treatment needs } \\
\hline Yes & $30(29.70)$ & $71(70.30)$ & $101(100)$ & 0.0132 & 2.28 & $1.18-4.40$ & & \\
\hline No & $18(15.65)$ & $97(84.35)$ & $115(100)$ & & Ref & & & \\
\hline \multicolumn{9}{|l|}{ Visible Plaque } \\
\hline Yes & $27(28.72)$ & $67(71.28)$ & $94(100)$ & 0.0437 & 1.94 & $1.01-3.71$ & & \\
\hline No & $21(17.21)$ & 101 (82.79) & $122(100)$ & & Ref & & & \\
\hline
\end{tabular}

point to a higher prevalence of enamel defects in populations with low socioeconomic status. As Brazil is a country marked by social inequalities, reflected by the levels of oral health of its population, understanding the relationship of enamel defects, caries and socioeconomic conditions can help managers and health professionals in the process of organizing actions and oral health services offered to the population.

DDE is often associated with higher rates of caries experience among affected children ${ }^{10,12}$. The correlation between enamel defects and childhood caries is an important issue for the polarization of caries experience in underprivileged populations ${ }^{9,12}$. Brazil is a country with significant socioeconomic discrepancies, which result in an uneven distribution of oral diseases in the population. Despite its small sample size, in this study, after adjustment of the OR for the effects of covariates, it was observed that children with HSPM had a 2.28 higher risk of having dental caries in childhood. This highlights the importance of hypomineralized enamel defects as a

\section{ACKNOWLEDGMENT}

The authors are grateful to all Brazilian researchers who, even in the face of great difficulties, voluntarily contribute to the construction of science and the dissemination of knowledge among different ethnicities and nations. The authors also thank FAPESP, FOP-UNICAMP for their support, and the parents and children who participated in this study. risk indicator for the development of dental caries, and this evidence should be considered by public health dentists when planning health promotion actions aimed at this group.

The high prevalence rates of HSPM and its potential to affect children's oral health suggest the importance of enamel defects being included as an indicator of dental health status in oral epidemiological studies of children. The understanding of the relationship between HSPM and dental caries has implications for public health planners, and the result of this study shows the need for further research into the influence of HSPM on the pattern of dental caries in childhood development.

\section{CONCLUSION}

It is concluded that there is a positive association between HSPM and dental caries in children, even after adjustment for clinical and demographic variables. This highlights the importance of HSPM in the development of dental caries, which should be considered when planning public health actions.

\section{FUNDING}

This work was supported by Grant \# 2010/13187-3, São Paulo Research Foundation (FAPESP).

\section{CORRESPONDENCE}

Prof. Dr. Fábio Luiz Mialhe

Avenida Limeira 901, Areão

Piracicaba, SP, Brasil - ZIP 13414-903

mialhe@unicamp.br 


\section{REFERENCES}

1. Ghanim A, Manton D, Mariño R, Morgan M, Bailey D. Prevalence of demarcated hypomineralisation defects in second primary molars in Iraqi children. Int J Paediatr Dent 2013; 23:48-55.

2. Oyedele TA, Folayan MO, Oziegbe EO. Hypomineralised second primary molars: prevalence, pattern and associated co morbidities in 8- to 10-year-old children in Ile-Ife, Nigeria. BMC Oral Health 2016;16:65.

3. Garot E, Denis A, Delbos Y, Manton D, Silva M, Rouas P. Are hypomineralised lesions on second primary molars (HSPM) a predictive sign of molar incisor hypomineralisation (MIH)? A systematic review and a meta-analysis. J Dent 2018;72:8-13.

4. Weerheijm K, Duggal M, Mejàre I, Papagiannoulis L, Koch G, Martens LC, Hallonsten A-L. Judgement criteria for molar-incisor hypomineralisation (MIH) in epidemiologic studies: a summary of the European meeting on MIH held in Athens, 2003. Eur J Paediatr Dent 2003;4:110-113.

5. Silva MJ, Scurrah KJ, Craig JM, Manton DJ, Kilpatrick N. Etiology of molar incisor hypomineralization: a systematic review. Community Dent Oral Epidemiol 2016;44:342-353.

6. van der Tas JT, Elfrink MEC, Heijboer AC, Rivadeneira F, Jaddoe VWV, Tiemeier H, Schoufour JD, Moll HA, et al. Foetal, neonatal and child vitamin D status and enamel hypomineralization. Community Dent Oral Epidemiol 2018;46:343-351.

7. Elfrink MEC, ten Cate JM, Jaddoe VWV, Hofman A, Moll HA, Veerkamp JSJ. Deciduous Molar Hypomineralization and Molar Incisor Hypomineralization. J Dental Res 2012; 91:551-555.

8. Costa FS, Silveira ER, Pinto GS, Nascimento GG, Thomson WM, Demarco FF. Developmental defects of enamel and dental caries in the primary dentition: A systematic review and meta-analysis. J Dent 2017;60:1-7.

9. Oliveira AFB, Chaves AMB, Rosenblat A. The influence of enamel defects on the development of early childhood caries in a population with socioeconomic status: a longitudinal study. Caries Res 2006;40:296-302.

10. Zhou Y, Yang JY, Lo ECM, Lin HC. The Contribution of life course determinants to early childhood caries: A 2-year cohort study. Caries Res 2012;46:87-94.
11. Costa Silva CM, Ortega EMM, Mialhe FL. The impact of molar-incisor hypomineralisation on dental caries in permanent first olars: A prospective cohort study. Oral Health Prev Dent 2017;15:581-586.

12. Folayan MO, Alade M, Adeniyi A, Tantawi MEI, Finlayson TL. Association between developmental dental anomalies, early childhood caries and oral hygiene status of 3-5-yearold children in Ile-Ife, Nigeria. BMC Oral Health 2020; $20: 1$.

13. Antunes JLF, Narvai PC, Nugent ZJ. Measuring inequalities in the distribution of dental caries. Community Dent Oral Epidemiol 2004;32:41-48.

14. Costa-Silva CM, Paula JS, Ambrosano GMB, MIalhe FL. Influence of deciduous molar hypomineralization on the development of molar-incisor hypomineralizarion. Braz J Oral Sci. 2013;4:335-8.

15. World Health Organization: Oral health surveys basic methods. $4^{\text {th }}$ ed. Geneva: WHO 1997; 36-44

16. Mahoney EK, Rohanizadeh R, Imail FSM, Kilpatrick NM, Swain MV. Mechanical properties and microstructure of hypomineralized enamel of permanent teeth. Biomaterials 2004; 25:5091-5100.

17. Jälevik B, Dietz W, Nóren JG. Scanning electron micrograph analysis of hypomineralized enamel in permanent first molars. Int J Paediatr Dent 2005;15:233-240.

18. Costa Silva CM, Ambrosano GMB, Jeremias F, Souza JF; Mialhe FL. Increase in severity of molar-incisor hypomineralization and its relationship with the colour of enamel opacity: a prospective cohort study. Int J Paediatr Dent 2011;21:333-341.

19. Cho SY, Ki Y, Chu V. Molar Incisor hypomineralization in Hong Kong Chinese children. Int J Paediatr Dent 2008;18: 348-352.

20. Costa-Silva CM, Jeremias F, de Souza JF, Cordeiro RC, Santos-Pinto L, Zuanon AC. Molar incisor hypomineralization: prevalence, severity and clinical consequences in Brazilian children. Int $\mathrm{J}$ Paediatr Dent 2010;20:426-434.

21. Gabardo MCL, Silva WJ, Moysés ST, Moysés SJ. Water fluoridation as marker for sociodental inequalities. Community Dent Oral Epidemiol 2008;36:103-107. 